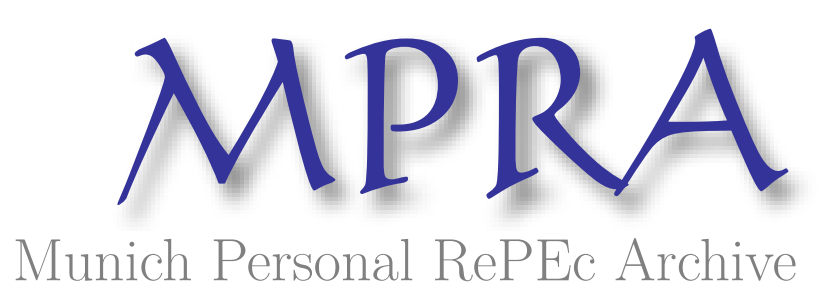

\title{
Trade openness, capital openness and government size
}

Liberati, Paolo

2007

Online at https://mpra.ub.uni-muenchen.de/44371/

MPRA Paper No. 44371, posted 15 Feb 2013 17:15 UTC 


\title{
TRADE OPENNESS, CAPITAL OPENNESS AND GOVERNMENT SIZE $\left(^{1}\right)$
}

\begin{abstract}
This paper provides empirical evidence of the relation between trade openness, capital openness and government expenditures in a cross-sectional time-series context. It is shown that capital openness is significantly and negatively related to government expenditures in line with the conventional wisdom that capital mobility may undermine the ability of governments to maintain larger public sectors. More importantly, the compensation hypothesis originally proposed by Rodrik (1998) and traceable back to Cameron (1978) is not in general supported by the data.
\end{abstract}

This paper has been published as:

Paolo Liberati (2007). Trade Openness, Capital Openness and Government Size. Journal of Public Policy, 27, pp. 215-247, doi:10.1017/S0143814X07000670. 
In a pioneering contribution, Cameron (1978) first unveiled the association between the openness of the economy and the size of the government for a sample of 18 OECD countries. The basic argument is that increasing trade openness may facilitate the development of social infrastructures - the density of unionisation, the scope of collective bargaining and the strength of labour confederations - and lead to an enlargement of the public sector. More recently, and for a greater number of countries, Rodrik (1998) has argued that increasing external economy's exposure (again trade openness) may lead to more demand for public expenditures to compensate for increasing external risk, a process that has become popular as the compensation hypothesis.

Recent contributions have challenged this result, suggesting that either the size of governments has not changed to mitigate the effects of greater openness (Islam 2004) or that causality from trade openness to government size is not supported by data (Molana et al. 2004). Garen and Trask (2005) also argue that considering non-budgetary measures of government size (like government ownership, price controls, barriers to trade, etc.) less open countries tend to have larger public sectors.

Most of this debate has however focused on one dimension of openness, namely trade openness. This is not fully justified on an empirical ground, as capital openness, over time, has gained increased quantitative importance in all advanced countries. In the main OECD countries included in this paper (see Table A.1 in Appendix for the complete list), the weighted share of trade openness on their total GDP was 21.8 per cent in 1975 and 41 per cent in 2000. The corresponding average figures for foreign direct investments (FDI) are 0.9 per cent in 1975 and 10.8 per cent in 2000 - 11 times as much, while those for portfolio investments (PI) are 0.7 per cent in 1975 and 12.3 per cent in 2000 - about 16 times as much.

At the same time, general government expenditures have climbed, on average, from 36.8 per cent in 1970 to 50.5 per cent in 1993 and then have fallen to about 44 per cent in 2000 .

A natural question to ask is therefore whether capital openness may play an autonomous role in shaping government size and may affect the validity of the compensation hypothesis. By transposing Rodrik's argument, one could argue that capital openness would further increase the risk of external economy's exposure and, by this way, the demand for compensating public expenditures. On the other hand, increasing degrees of capital openness may lead to higher mobility of tax factors and leave governments with a reduced ability to maintain larger public sectors, a case that is usually referred to as the efficiency hypothesis. Following this logic, the potential increasing demand for additional expenditures induced by the compensation hypothesis could not be easily matched by an increasing supply. The net effect of these two opposite forces is therefore a matter for empirical investigation.

This paper sheds some light on the relative importance of the two hypotheses and on the role of both trade and capital openness across countries and over time. First, it is shown that capital openness and government size are persistently negatively associated, which gives support to the efficiency hypothesis. Second, evidence is provided that the compensation hypothesis proposed by Rodrik (1998) and traceable back to Cameron (1978) is hardly verified. Third, results are established for both levels and changes of the relevant variables. 


\section{Reviewing theoretical and empirical studies}

The theoretical effects of economic openness on the size of public sectors may be summarised by two main positions (Schulze and Ursprung, 1999). On the one hand, the compensation hypothesis has recently gained much interest. According to it, larger public sectors would be demanded in more open economies to compensate for external risk and for the increased level of economic inequality associated to openness. On the other hand, an efficiency hypothesis has developed (also known as conventional wisdom), which highlights that smaller public sectors would be supplied by national governments when economic openness entails an increased mobility of production factors.

In the same way as in the theory of fiscal federalism local governments may be "too small" within national boundaries to apply certain kinds of taxes and to develop certain kinds of public expenditures (Oates, 1972), national states may become "too small" in an international context to take advantage from the full array of taxes and expenditures. As suggested by the literature on tax competition, mobility may cause a downward pressure on tax revenues and lead to an ultimate downward pressure on public expenditures.

The net effect of the opposite forces of the compensation hypothesis and of the efficiency hypothesis is therefore rather uncertain from a theoretical point of view and it is basically a matter for empirical investigation.

Now, with regard to the compensation hypothesis, the prevailing literature has highlighted that citizens would demand more public expenditures in response to increased trade openness (e.g. Ruggie 1982; Garrett 1998b; Rodrik 1998). However, the basic tenet of the efficiency hypothesis, is that governments may collect less taxes and can hardly run budget deficits in response to an increase of capital openness. The reason is that mobile capital may easily disapprove of unpalatable tax policies or lax budget policies by moving abroad. This would ultimately lead to a tighter expenditure policy.

According to some authors, this line of causality is supported by the fact that some of the most important welfare reforms have occurred at the same time in which capital openness in many countries has increased (Gould 1996; Myøset 1996; Page 1997; Moses 2000; Swank 2002).

What does the empirical evidence suggest? In a pioneering paper on the expansion of the public economy, Cameron (1978) found a positive association between trade openness and the size of the public sector, but no attempt was made to include capital openness in the analysis presumably because capital flows, in the most industrialised countries, were heavily controlled for. For example, the United States fully liberalised capital markets in 1974 and they were one of the first countries to go through this process.

Rodrik (1998) has thoroughly re-established the positive association between trade openness and the size of the public sector, justifying it by the need of social insurance against additional external risk and extending the empirical evidence to more than a hundred countries among developed and developing countries. However, also in this case, no attempt has been made to control for capital openness.

More recently, Sanz and Velázquez (2003) have investigated the effects of the openness of the economy, including the averaged stock of inward and outward foreign direct investments as a proxy for capital openness. Their main finding is that openness would be positively associated to the share of health and social security expenditures in 
total government expenditures and negatively associated to education, housing, transport and communication shares of public expenditures (challenging Rodrik's findings for subcategories of expenditures). Extending the Rodrik's argument, the authors argue that countries with greater amounts of stocks of FDI would experience more risk in total employment, as multinationals may change location easier than "national" companies (see also Tanzi 2000; White 2003).

Quinn (1997) also finds evidence that capital liberalisation is associated to larger government spending. In the same vein, Bretschger and Hettich (2002) provide evidence that both capital openness and trade openness may positively affect the level of social welfare expenditures, supporting the compensation hypothesis and extending it to capital openness.

On the other hand, Iversen and Cusack (2000) show that neither trade nor capital openness have any effect on government transfers and government consumption. The importance of capital openness (variously measured) for social welfare effort, has also been recently investigated by Swank (2002), again with no evidence of any relation. ${ }^{2}$ Recently, Dreher (2003) has provided for further empirical evidence that globalisation does not affect taxes and social policy in OECD countries. In particular, he shows that globalisation does not shift the tax burden from mobile capital to immobile labour and (relatively) immobile consumption. This follows a series of empirical papers from the political science literature where no consensus emerges on the possibility that the openness of the economy has reduced either capital or corporate income taxes or both (Garrett 1996; Swank 1998; Garrett 1998a, 1998b; Hallerberg and Basinger 1998).

Rodrik (1997) and Grubert (2001) have instead found a negative relation between the openness of the economy and the level of income taxes. Garrett (1999) provides evidence that the negative relation between openness and government size can be extended to changes of the corresponding variables. Bretschger and Hettich (2002) have also found that trade and capital openness are negatively associated to the corporate tax rate and positively associated to labour taxes, supporting the theory that the tax burden shifts towards less mobile tax bases in open economies. No significant relation with the corporate tax rates is instead shown in Swank (2002) and Slemrod (2004). Finally, Garen and Trask (2005) show that less open countries may have larger public sectors as measured by non-budgetary indicators.

As it stands, therefore, the empirical literature on the relationship between capital openness and government size is not conclusive, as different studies support a positive relation, the absence of any relation or a negative relation. In what follows, we add to the existing empirical literature, by showing: a) that levels of capital openness are negatively associated to government size; b) that levels of trade openness are not positively associated to government size; c) that these associations hold both in levels and in changes of the corresponding variables.

To this respect, the present paper does not support the Rodrik's argument, while it finds encouraging support for the efficiency hypothesis. 


\section{Hypotheses and empirical strategy}

The empirical investigation will focus on the following two maintained hypotheses:

Hypothesis 1 - Capital openness is associated with a smaller government size.

Hypothesis 2 - Trade openness is not associated with a larger government size.

Hypothesis 1 is a test of the efficiency hypothesis. As previously stated, the basic tenet is that higher capital openness would make it harder to tax and to issue public debt to finance public expenditures as capital may easily move abroad.

With capital openness, tax and expenditure policies may indeed stimulate exit to the extent that investors do not agree on the nature of public spending, do not agree on the present level of tax burden and/or anticipate additional future tax burden to finance increasing levels of public spending. As stressed by Garrett (1999), especially financial capital "is usually thought to disapprove of all government policies that distort markets, and excessive government spending is among the most prominent villains".

Hypothesis 2 is a test of the absence of the compensation hypothesis. The basic tenet is that if the efficiency hypothesis is verified, the compensation hypothesis would disappear, even though this does not necessarily entail a reversed sign of its association with trade. More likely, however, the interaction between trade and capital openness is expected to be dominated by the efficiency hypothesis.

According to this hypothesis, the net outcome would be a smaller size of the public sector. The extension of the compensation hypothesis to capital openness is thus explicitly challenged in this paper. On the contrary, the extension of the efficiency hypothesis to the relation between trade openness and government size is thought to be a more likely outcome.

\section{II.1 The measure of government size}

Government size is measured by central government expenditures. Two natural questions to ask are: a) why public expenditures should be used as a proper measure of government size instead of taxes; $b$ ) why central governments expenditures are used instead of general government expenditures.

With regard to the first question, a number of issues can be considered. First, the compensation hypothesis is stated in terms of expenditures and not of taxes. Challenging this hypothesis would therefore require to play on the same field.

Second, the nature of the compensation is such that citizens demand more expenditures - and not directly more taxes. Even though the compensation hypothesis would suggest that it is redistributive expenditures that should increase more, the first element to test is whether capital openness has any effect on the level rather than on the composition of public spending. As Garrett (1999) has argued, public spending is "perhaps the most fundamental indicator of government economic activism".

Third, taxes and expenditures move in the same way only when deficit financing is ruled out. Deficit-financing, has been an important way to expand public expenditures in 
many countries over time. With budget deficits, a reduction of public expenditures may be associated with a stability of tax revenues. In this case, analysing taxes might be misleading. Considering public expenditures allows one to include in a single indicator all possible channels through which the efficiency hypothesis may affect the size of public sectors.

Fourth, as argued by Schulze and Ursprung (1999), in open economies governments compete by means of both taxes and expenditure policies to attract tax bases. Looking at taxes only may again be misleading, as a given level of taxes may be associated with composition of public spending that may or may not favour international investors. ${ }^{3}$

More crucial is the issue of whether central governments (CG) expenditures represent a proper indicator of government size. The answer is not clear-cut. Yet, there are some reasons justifying the use of this indicator.

First, as central government and local government behaviours may significantly differ in terms of expenditure policies (especially when local autonomy is strong), it can be of interest to isolate the effects of openness on the two government levels (see, for example, Verdier and Breen 2001; Garrett and Rodden 2003). The absence of any effect of openness on general government expenditures would indeed not imply that openness has no effect on government expenditures, as this outcome might conceal opposite forces playing at central and local government levels. Therefore, disentangling the effects on $\mathrm{CG}$ expenditures gives an informative advantage.

Second, as the validity of the compensation hypothesis, if any, is likely to entail a greater redistributive effort of central governments - where most of the redistributive function is concentrated - the use of CG expenditures is a natural candidate for this test. Nevertheless, it is extremely important to test whether the results are sensitive to the definition of government expenditures. Therefore general government (GG) expenditures have been used to test the main conclusions of the paper, even though the switch from central to general government definitions entails a significant loss of observations. Availability of data is therefore also a non-negligible argument to use CG expenditures, as one can easily verify from table A.1 in Appendix.

\section{II.2 The measure of trade and capital openness}

The measure of trade openness used in this paper is rather standard. It is defined as the sum of exports and imports as a percentage of GDP. This indicator aims at estimating the importance of total trade relative to the size of the domestic product.

Measurement of capital openness, instead, has been usually fraught with difficulties. One of the main issue is what is meant by capital openness. As argued by Montiel (1994: 311), for example, "capital openness ... is a somewhat amorphous concept, not clearly defined in many applications and difficult to measure". On the other hand, most of the empirical literature has converged towards the idea that capital openness indicators should indicate either actual or potential capital mobility.

Some issues should therefore be taken into account. First, should foreign direct investments or portfolio investments be considered or both? ${ }^{4}$ Second, are inflows or outflows that best measure of capital openness? Third, are capital flows a more reliable 
indicator of capital mobility than stocks? Fourth, should flows and stock be disregarded in favour of alternative indicators?

With regard to the first issue, Kant (1996) has shown that measures based on foreign direct investments are usually preferred, as they have been found highly correlated with capital flights. The distinction made by Singh (2003) in long-term flows (FDI) and shortterm flows (PI) may also help understand that PI may be more speculative, while FDI may be thought of as more permanent flows. Claessens et al. (1995) have instead argued that this difference is becoming weaker, as what they call a long-term «bricks and mortar» investment (a FDI-type) can now be promptly converted into a liquid asset through derivatives and hedge funds.

With regard to the second issue (inflows or outflows), most of the empirical literature (see for example Bretschger and Hettich 2002) has focused on the effects of outwards FDI on government variables (either taxes or expenditures). This is mainly justified by the fact that outflows may have more important consequences on government resources than inflows.

However, from the point of view of measuring capital openness, confining the attention to outflows may make some countries appear rather "close" if they attract much more capital than what it flows out from the country. In the same vein, using net flows (i.e. the difference between inflows and outflows) may be highly misleading, as a given net measure may be consistent with any gross flow magnitudes (Kar 1983). In turn, different gross flows may cause rather different consequences on the size of the public sector. If it is true, a strong preference should be therefore assigned to gross flows, as net flows are more likely to underestimate the size and the importance of capital openness (Whitman 1969).

The third issue, flows or stocks, is particularly cogent, as it may give rise to significantly different pictures. The empirical literature is rather controversial on this issue. For example, Sanz and Velázquez (2003) use stocks; Bretschger and Hettich (2002) use flows. One flaw of using flows lies on the fact that zero capital flows is a necessary but not sufficient condition for financial autarky. Strongly integrated capital markets may end up with zero capital flows.

Montiel (1994), however, argues that countries with higher potential capital integration would also experience large actual capital flows, which points to flows as an (on average) correct measure for capital mobility. Also, flows best capture mobility, as it is (potential) flows that may prevent a given country to change its taxing/expenditure behaviour, not the mere presence of a given capital stock outside the country.

One flaw of using stocks, on the other hand, is how to measure them, i.e. which value is to be assigned to investments occurred in past years. The evaluation of stocks is often based on historical costs rather than on current market values. ${ }^{5}$ This may raise more serious problems of interpretation of results than in the case of flows.

With regard to the fourth issue, a debated question is whether capital openness should be measured as either actual or potential mobility. Potential mobility could be a more satisfactory indicator for capital openness, better reflecting the threat of capital flows. For this reason, part of the literature has focused either on qualitative indexes of capital market liberalisation ${ }^{6}$ or on other quantitative measures, as the interest rate differentials (in particular covered interest rate differentials calculated with forward foreign-exchange 
rates), interest arbitrage, real interest parities, etc. (Montiel 1994; Swank 1998). On the other hand, all these measures have imperfections.

Taking into account all these issues, the choice of this paper has fallen on measuring capital openness by two distinct measures: the algebraic sum of inward and outward foreign direct investments (FDI) on GDP; the algebraic sum of inward and outward portfolio investments (PI) on GDP. The first measure will be referred to as FDI openness; the second as PI openness. The choice of using gross flows aims at measuring the importance of capital flows on the total economy and to give a more proper picture of the total mobility of capital across countries. This also limits the risk of polluting the results with the possible influence of those factors that may contemporaneously affect government expenditures and capital flows. ${ }^{7}$

\section{II.3 Data}

The focus of the analysis will be on the main European countries, but the United States, Canada, Australia, New Zealand and Japan will also be included, in particular because they experienced a liberalisation of capital flows (US and Canada in 1974, Australia and New Zealand in 1984-85 and Japan throughout the '80s) before it was introduced in Europe in the Nineties (Helleiner 1994). All these countries are developed countries, where public expenditures are a significant part of the gross domestic product, formal democratic regimes are in place and where redistribution, even though at various degrees, is an important issue on the agenda of policy-makers. Developing countries have been excluded as, on average, they are countries with relevant cultural, historical and institutional differences (Akai and Sakata 2002).

Data on exports, imports and capital flows (foreign direct investments and portfolio investments) are taken from the International Financial Statistics (IFS) of the International Monetary Fund (IMF). The same source provides for data on consolidated central government expenditures, which are mainly used for the analysis. To get reasonably long series on general government expenditures (i.e. including intermediate and local government levels), instead, recourse has been made to OECD data. When interpreting results, therefore, caution must be used as, in some cases, data from different sources are combined. The definition and source of all variables used in this paper are reported in table A.2 in Appendix.

As discussed in Section IV.1, the core of the analysis will be based on the use of central government expenditures. Data used cover a reasonable number of years and countries - with the exception of Germany, observed only after the re-unification process - while the use of general government expenditures generates a non-negligible loss of observations. Outliers have been identified and dropped according to the method proposed by Hadi (1992) for multivariate analysis. This has led to identifying 1 outlier in the measure of trade openness, 15 for FDI openness, 2 for portfolio openness, 1 for government deficit and 3 for current account balance. 


\section{II.4. Econometric issues}

The baseline relation between government size and openness is estimated using the following equation:

$$
G S_{i, t}=\alpha+\beta_{1} T R A D E_{i, t}+\beta_{2} F D I_{i, t}+\beta_{3} P I_{i, t}+\sum_{p=1}^{P} \gamma_{p} Z_{i, t}^{p}+e_{i, t}
$$

where $G S$ is government size; TRADE is defined as the sum of exports and imports as a share of GDP; FDI is defined as the sum of inward and outward foreign direct investments as a percent of GDP; $P I$ is defined as the sum of inward and outward portfolio investments as a percent of GDP; $Z$ is a vector of control variables, including in most cases real per capita income in US\$, a dummy for federal countries, the government deficit and the current account balance both in percentage of GDP and a time trend. Other control variables have also been included for sensitivity analysis.

Following Bretschger and Hettich (2002), measures of trade and capital openness are corrected for country size. ${ }^{8}$ They suggest first regressing the measure of openness on an indicator of country size and then using residuals from this regression as an unbiased measure of openness. By this way, the residuals of the regression describe that part of trade and capital openness that is not explained by country size. These residuals can therefore be taken as a size-neutral measure of openness. Using this latter measure makes Germany and the United States more open than average compared with the traditional measure of trade openness. At the same time, Austria, Denmark, Finland, Norway and Sweden are defined as less open than average. For all other countries, the size-neutral measure gives the same information released by the traditional measure. This correction also leaves Australia and Norway with less capital openness than average and Germany and the United States with more capital openness than average.

The analysis of time-series cross sections also entails the treatment of some other preliminary issues. With panel data, possible heteroskedasticity across panels should be dealt with. Furthermore, the error terms of different panels may be correlated. Both nullhypotheses of no panel-level heteroskedasticity and no cross-sectional correlation are rejected. This would lead to introducing an estimator that could take into account heteroskedastic and contemporaneously correlated panels. Also a test for autocorrelation within each panel has been performed via the time-series cross-section equivalent of the standard Lagrange multiplier test. The null hypothesis of no autocorrelation cannot be rejected only in the case of Austria, Canada, Germany and Greece. Since the coefficients of the lagged residuals are also different among countries, estimation has been carried out by introducing a country-specific $\mathrm{AR}(1)$ process, by which $e_{i, t}=\rho_{i} e_{i, t-1}+\varepsilon_{i, t}$, where $\varepsilon$ has the usual assumptions of i.i.d. $\left(0, \sigma^{2}\right)$.

A test for equality of intercepts across countries is also performed to understand whether either fixed or random effects might be a better estimator than OLS on pooled data. The null hypothesis of equality of intercept is rejected, which means that OLS on pooled data are inconsistent. The choice between fixed or random effects is usually based on a Hausman test for the unbiased random effect estimator. Since there are no significant 
differences in the estimated coefficients between the two methods, a fixed effect estimator could be safely implemented. ${ }^{9}$

The reason for reporting results from both methods is that fixed effects have a more problematic interpretation when the sample used does not represent a closed and exhaustive set of units. Countries are selected on the basis of data availability and do not exhaust any particular geographical region. On the other hand, the potential importance of unobserved effects across countries (e.g. political and societal preferences on the size of government) suggests fixed effects as an appropriate estimator.

It is also worth noting that the fixed effects estimator uses variation within units and disregard variation between units. In other words, fixed effects take into account the time series component of the data, the reason why results from this method should be interpreted as short-run effects. Random effects, instead, use a matrix-weighted average of the within and the between estimator and therefore takes into account both long-run and short-run effects. A further possibility, which is also used as a sort of sensitivity analysis in this paper, is the use of the Feasible Generalised Least Squares (FGLS) estimator, that carries out a pooled estimation on quasi-demeaned data, i.e. on data formed by subtracting only a fraction of the averages. ${ }^{10}$ Finally, in order to introduce dynamics in the estimated equation, results from the Arellano-Bond estimator will also be discussed. ${ }^{11}$

Finally, a test for Granger-causality has been performed according to the methodology developed by Holtz-Eakin et al. (1988). Given $m$ time periods and $i=1, \ldots, N$ units a test for no causality would be a test of the joint hypothesis Ho: $\sum_{j=1}^{m} \delta_{j}=0$ in the model:

$$
y_{i, t}-y_{i, t-1}=\alpha+\sum_{j=1}^{m} \beta_{j}\left(y_{i, t-j}-y_{i, t-j-1}\right)+\sum_{j=1}^{m} \delta_{j}\left(x_{i, t-j}-x_{i, t-j-1}\right)+\left(u_{i, t}-u_{i, t-1}\right)
$$

where $\delta$ s are the coefficients of the first difference of lagged independent variables for $m$ time periods. ${ }^{12}$ Data supports only a causality relation from FDI to government expenditures, while this causality is not found in the case of trade and PI openness. Furthermore, the absence of causality from government size to FDI is not rejected.

\section{Results}

\section{III.1 Time trends}

As a preliminary step of the analysis, it is worth considering the evolution over time of the main variables. A simple way to perform this task is to regress all variables on a set of time (period) dummies. Taking as a base the average of the period 1965-1975, Table 1 shows that all relevant variables (government size, trade and both capital variables) have an upward trend in the period covered by the analysis. Of particular interest is the dynamic of government expenditures. In the case of CG expenditures, the time trend is particularly marked in the first two decades, but not in the third where the coefficient is 
statistically significant at 10 per cent. In the case of GG expenditures, time dummies are always significant, but the shift in the last decade is the lowest among the three, which might imply that government expenditures are growing at a slower rate than before.

On the other hand, both foreign direct investments and portfolio investments, as a share of GDP, show a larger shift in the last decade (between 1995 and 2005, about five times and a half the shift calculated for the previous decade in the case of FDI and about three times the shift of the previous decade for PI). For trade openness the calculated shift is about twice as much the shift of the previous decade.

Overall, government size is growing at a slower rate, while FDI and PI grow much faster than trade openness. Changing the base period does not change the interpretation.

\section{III.2. Capital openness and central government expenditures}

Table 2 is the core of the analysis. It reports a set of 7 regressions. Columns $A$ to $E$ include all available countries (20), while columns $F$ and $G$ focus on the European countries (15). Regressions differ by the estimator used. Particularly important are the signs of the coefficients of the openness variables. A positive sign of the coefficient of trade openness would give support to the validity of the compensation hypothesis. A positive sign attached to the coefficients of FDI and PI openness would extend the validity of this hypothesis also to the capital openness. A negative sign, instead, would support the efficiency hypothesis.

A set of control variables (government deficit, current account balance, per capita income, population, federal government structure and a time trend) is also included in all regressions in order to take into account elements of pressure on government expenditures. In particular, government deficit would capture the need to contain public expenditures with a non-balanced budget. The current account balance seeks to take into account that deficits may require, for example, higher interest rates than in a counterfactual scenario. This would impair investments at home causing a more stringent government budget constraint. Per capita income and population would take into account the main economic and demographic pressures on the level of public expenditures; the dummy on federal countries would capture the fact that central government expenditures may be lower in more decentralised countries; finally a linear time trend would capture the natural upward evolution of economic variables, reducing the risk of introducing spurious correlation among variables.

Consider first the regressions with all available countries included (columns $A$ to $E$ ). The only case in which trade openness has a positive and statistically significant coefficient (i.e. the compensation hypothesis is supported) is in column A, where OLS on pooled data are used. Yet, the coefficients of FDI and portfolio openness are both negative, greater in size and statistically significant. However, OLS on pooled data imply the equality of intercepts across units, a hypothesis that is - as discussed above - rejected by the data.

It is worth noting that in the context of pooling, the use of the Prais-Winsten panel corrected estimator (PCSE) - column $B$ - would leave unaltered the negative sign of FDI and portfolio openness, while reversing the sign of the coefficient of trade openness. In 
other words, the compensation hypothesis disappears. This is even truer when a Feasible Generalised Least Squares (FGLS) is used (column $C$ ). In this latter case, the coefficient of portfolio openness loses its statistical significance.

As discussed above, the inclusion of different countries and the probability of "unobserved effects" suggest to perform both fixed and random effects estimations columns $D$ and $E$. In both cases, all openness variables are negatively associated to CG expenditures, supporting the efficiency hypothesis and not the compensation hypothesis. This result is not driven by the presence of extra-European countries, as columns $F$ and $G$ (fixed and random effects, respectively - 358 observations on 15 countries) show that trade openness and FDI openness are both still negatively associated to government size. Portfolio openness has also a statistically significant negative coefficient when fixed effects are used, becoming significant only at 10 per cent level when switching to random effects. $^{13}$

Overall, the econometric analysis of Table 2 provides for a rather clear support to the hypothesis that capital openness - especially FDI openness - might be an element of downward pressure on the level of government expenditures, therefore supporting the efficiency hypothesis and departing from a significant part of the existing literature. At the same time, the coefficient of trade openness does not support the compensation hypothesis. This casts some doubts on the general validity of the Rodrik's result when capital openness is explicitly introduced into the analysis.

The previous analysis can be further extended to consider changes - rather than levels - of the corresponding variables and to introduce some dependency of government expenditures on their own past changes. In other words, equation (1) is now estimated using first differences of explanatory variables with some (variable) lag structure on both the dependent and the explanatory variables. To achieve this aim, the Arellano-Bond (1991) estimator is used. Results are reported in Table 3.

Consider first column $A$, where explanatory variables are treated as truly exogenous and two lags of the dependent variable are introduced into the equation. Again, the coefficient of FDI openness is negative and statistically significant, while portfolio openness is not robust to this specification. Furthermore, the coefficient of trade openness is again negatively associated to government expenditures, denying support to the compensation hypothesis. However, the Sargan test of the null hypothesis of instruments validity for this specification is rejected, which might signal either that explanatory variables may be better treated as predetermined or endogenous rather than exogenous or that the structure of lag is wrong.

A natural alternative is therefore to treat explanatory variables as predetermined, i.e. as variables for which the realization of the error term has some effect on their future realisation. This requires instrumenting explanatory variables by levels lagged one or more periods. Results are reported in column $B$. Also in this case, the coefficient of trade openness and both coefficients of capital openness are negatively associated to government expenditures - again a support for the efficiency hypothesis. Note that, in this case, the Sargan test does not reject the null hypothesis of instrument validity and the absence of second-order autocorrelation leads to consistent estimators, which is an indicator that the explanatory variables are better modelled as predetermined. 
Switching to a treatment of explanatory variables as endogenous (which requires levels lagged 2 or more periods as valid instruments), does not change the main result of the analysis (column $C$ ). The coefficients of trade openness and capital openness are again negatively associated to government expenditures and are therefore robust to this alternative treatment.

Introducing some lag structure (i.e. a lag of first differenced endogenous and predetermined variables) does not change the outcome. Columns $D$ and $E$ show that the negative sign on the coefficient of FDI openness and trade openness resists the introduction of the corresponding lagged (one-period) variables, but portfolio openness does not. Column $F$ also shows that the efficiency hypothesis still holds after introducing an interaction term between changes in trade and changes in capital openness (trade times capital). This term is not statistically significant and does not affect the main conclusions. Finally, column $G$ shows that the result is not driven by extra-European countries, as both FDI and trade openness have negative and statistically significant coefficients also when the analysis is circumscribed to European countries. Finally, using a simple firstdifferenced model with FGLS (column $H$ ), for all countries and all years, again reveals that changes in trade openness and in capital openness are negatively related to central government expenditures.

\section{III.3 Capital openness and general government expenditures}

In order to exploit the maximum availability of data, the previous sections have dealt with CG expenditures. In this section, we perform some regressions using data on GG expenditures (i.e. including intermediate and local government levels). This is rather important to test the robustness of the results to different specifications of government size. Results are reported in Table $4-$ from column $A$ to $F$. Fixed effects, random effects and the Arellano-Bond estimator have been applied to all available countries and to the subset of European countries. The coefficient of FDI openness (or its first difference) is negative and statistically significant in all specifications, again supporting the efficiency hypothesis. This does not necessarily imply that local government expenditures also bear a downward pressure; yet, the effect of capital openness on CG expenditures seems enough important to drive GG expenditures down. It is worth noting that the same negative association emerges for trade openness, which represents a strong rejection of the compensation hypothesis. The coefficient of portfolio openness, on the other hand, does not show a clear-cut result.

The recourse to general government expenditures also allows a more detailed analysis of subsets of public spending. In particular, using OECD data, it is possible to test the influence of capital openness on the aggregate of social welfare expenditures. This is usually considered a more direct test of the compensation hypothesis, as, if any, demand for more public expenditures should be directed to the more redistributive items of the public budget.

To this purpose, Table 4 - in columns $G$ to $I$ - reports the results obtained using the sum of health, education and social protection expenditures in percentage of GDP as a dependent variable. The three basic specifications - fixed effects, random effects and the 
Arellano-Bond estimator - are again performed with the same explanatory variables. All methods once again confirm the negative relation between social expenditures and FDI openness, while the compensation hypothesis do not even pass this test on the most favourable subset of public spending.

It is however worth noting that using social welfare expenditures considerably restricts the number of observations and countries (121 and 14, respectively) to the most recent period. Therefore, indirectly, this also provides a sensitivity test of the general result, making them robust to the choice of the definition of public spending, the period and the countries included in the analysis.

Finally, columns $J$ and $K$ use a definition of GG expenditures excluding interest expenditures, while columns $L$ and $M$ use a definition of GG expenditures excluding both interest and defence expenditures. The former kind of expenditure is excluded as not directly controlled for by the public sector; the latter because it answers a different logic from the compensation and the efficiency hypothesis. Also in this case, the sign of FDI openness is persistently negative, while there is no evidence of the compensation hypothesis.

Overall, the use of general government expenditures does not change the main theme of the paper, i.e. a stable support for the efficiency hypothesis and a rejection of the compensation hypothesis.

\section{III.4. Sensitivity analyses}

Table 5 provides for further alternative specifications of the basic regression in order to test the robustness of the result. Column $A$ includes squared terms of the openness measures. Quite interestingly, the combined effect of the coefficients on trade openness gives rise to a sort of curvilinear hypothesis, by which government expenditures increases with trade openness up to a certain level of it, after which government expenditure would start to decrease. In the case of FDI and portfolio openness, a curvilinear relation is not supported, as the coefficients of squared terms are statistically not significant.

Column $B$ tests the hypothesis that the result could be driven by some countries with a particularly high level of government expenditures, i.e. the Nordic European countries (Finland, Norway and Sweden). This is not the case, as the coefficient of FDI openness is still negative and significant when excluding these countries. On the other hand, trade openness has now a positive relation with government expenditures, yet the size of its coefficient is much lower than that attached to FDI openness. This means that for a given level of trade or FDI openness, the downward pressure on government expenditures would be larger than the upward pressure possibly generated by the compensation hypothesis.

Column $C$ reintroduces the time trend and the dummy for federal countries and includes political control variables - a dummy variable for centre-left governments in power and a dummy variable for proportional electoral systems. Again, the sign of the FDI openness is negative and statistically significant.

Column $D$ introduces a split between inwards and outwards capital flows (for both foreign direct investments and portfolio investments). This alternative specification 
preserves the sign and the meaning of the coefficients of outwards flows but not those of inwards flows. Note, however, that in this case there is a high correlation between these four capital openness variables, which may give rise to higher standard errors. Also note that splitting the measure is actually measuring a different thing from capital openness, as discussed in Section II.2. In any case, the efficiency hypothesis is not rejected, while the compensation hypothesis is not supported.

Finally, column $E$ reports the results obtained by including a one-period lagged dependent variable and two additional control variables - GDP growth and a dummy for the countries that have signed the Maastricht Treaty. Again, there is no evidence of a compensation hypothesis, while there is stable support for the efficiency hypothesis.

The negative association between FDI openness and government size also resists a cross-validation in which one country at a time is excluded from the basic econometric specification, using a panel corrected standard error estimator (results are not reported in table but are available from the author upon request).

\section{Conclusions}

In this paper, a rather strong support is given to the efficiency hypothesis, according to which capital openness is negatively associated to government size. We have shown that this result holds for both central and general government expenditures, for various definitions of general government expenditures and for different subset of countries and periods. The result is also very stable across econometric specifications. As it stands, it represents an important point of departure from the empirical literature aimed at associating larger governments with both trade and capital openness, at least for the set of countries considered here.

The limited number of countries used in this paper, however, should not be seen as a shortcoming. Elaborations on the UNCTAD database show that FDI inflows in OECD countries would account for about 78 per cent of world inflows in 1990, 52.6 per cent in 1997 and 77.8 per cent in 2000, while FDI outflows - in the same years - are 89.7 per cent, 78.6 per cent and 87.1 per cent of total world outflows. The system of OECD countries is therefore rather close and previous data suggest that if capital openness is to play any role in shaping government size it is likely to play it where capital actually flows. This might also explain why across-the-world conclusions may be difficult to achieve and why, when extending the number of countries, the effects of capital openness tend to dilute.

With regard to the size of the effect of FDI on government expenditures, the estimated coefficients imply low elasticities. If one takes into account the highest estimated coefficient of FDI and the average of both central and general government expenditures by country, the upper limit is represented by Switzerland - with a 0.33 per cent elasticity in absolute value in the case of $C G$ and a 0.091 per cent in the case of $G G$ - and the lower limit by Italy - with a 0.013 in the case of $C G$ and a 0.008 in the case of $G G$. All other elasticities are in absolute values below 0.1, which means that the effect of FDI, as expected, has not been disruptive on the size of the government until now, yet its negative sign - beyond being a strong result in itself compared with the existing literature - may 
signal that if the average level of capital flows increases in the future, government expenditures could suffer a larger reduction. Furthermore, since the highest coefficients of FDI are estimated in those cases in which only European countries are taken into account, it is here that capital flows will be more likely to undermine the size (and composition) of public expenditures.

On the other hand, the compensation hypothesis (associated to trade openness by Rodrik 1998) is denied general validity. Trade and capital openness share a negative relationship with government expenditures that does not seem to depend on the set of control variables included.

These findings have potentially important consequences from a public policy perspective, as they help explain why public policies in these countries might be more conservative - capital flows implicitly undermine larger public sectors.

All these results naturally point in the direction of further investigation of the relations between openness and government expenditures along two lines. First, they suggest that sub-regional analyses may be more informative than a worldwide analysis in which a large set of countries is included that widely differ in both institutional and economic settings. This latter methodology, which is widely adopted in the empirical literature, may indeed conceal possible different answers of public sectors to openness, something that is hardly captured by geographical dummy variables. Second, the use made in this paper of central and general government expenditures leaves open the question of how economic openness may affect public expenditures at intermediate and local government levels and their distribution across government levels, an issue that certainly merits further empirical investigation. 


\section{References}

Abdelal R. (2006), "Writing the Rules of Global Finance: France, Europe, and Capital Liberalization", Review of International Political Economy, 13, 1-27.

Akai N., Sakata M. (2002), "Fiscal Decentralization Contributes to Economic Growth: Evidence from State-Level Cross-Section Data for the United States", Journal of Urban Economics, 52, 93-108.

Aizenman J., Jinjarak Y. (2006), Globalization and Developing Countries - A Shrinking Tax Base?, NBER Working Paper 11933, Cambridge (MA).

Alesina A., Waczriag R. (1998), “Openness, Country Size and Government”, Journal of Public Economics, 69, 305-321.

Arellano M., Bond S. (1991), "Some Tests of Specification for Panel Data: Monte Carlo Evidence and an Application to Employment Equations", Review of Economic Studies, 58, 277-297.

Beck N., Katz J.N. (1995), "What to Do (and Not to Do) With Time-Series Cross-Section Data", American Political Science Review, 89, 634-647.

Bretschger L., Hettich F. (2002), «Globalisation, Capital Mobility and Tax Competition: Theory and Evidence for OECD Countries», European Journal of Political Economy, 18, 695-716.

Cameron D. (1978), "The Expansion of the Public Economy: a Comparative Analysis", American Political Science Review, 72, 1243-1261.

Claessens S., Dooley M., Warner A. (1995), "Portfolio Capital Flows: Hot or Cool?", World Bank Economic Review, 9, 153-174.

Dreher A. (2003), The Influence of Globalization on Taxes and Social Policy - An Empirical Analysis for OECD Countries, University of Exeter.

Frankel J.A., Romer D. (1999), "Does Trade Cause Growth?", American Economic Review, 89, 379-399.

Garen J., Trask K. (2005), "Do More Open Economies Have Bigger Governments? Another Look", Journal of Development Economics, 77, 533-551.

Garrett G. (1996), "Capital Mobility, Trade, and the Domestic Politics of Economic Policy", in Keohane R., Milner H. (eds), Internalization and Domestic Politics, Cambridge University Press, New York.

Garrett G. (1998a), Partisan Politics in a Global Economy, Cambridge University Press, New York.

Garrett G. (1998b), "Global Markets and National Policies: Collision Course or Virtuous Circle”, International Organization, 52, 787-824.

Garrett G. (1999), Globalization and Government Spending Around the World, Yale University.

Garrett G., Rodden J. (2003), "Globalization and fiscal decentralization”, in Kahler M., Lake D.A. (eds), Governance in a global economy: political authority in transition, Princeton.

Gould A. (1996), «Sweden: the Last Bastion of Social Democracy», in Vic G., TaylorGooby P. (ed.), European Welfare Policy: Squaring the Welfare Circle, New York, St. Martin Press.

Grubert H. (2001), "Tax Planning by Companies and Tax Competition by Governments: Is There Evidence of Changes in Behaviour?", in Hines Jr. J.R. (ed.), International 
Taxation and Multinational Activity, University of Chicago Press, Chicago and London.

Hadi A.S., (1992), "Identifying Multiple Outliers in Multivariate Data", Journal of Royal Statistical Society, 54, 761-771.

Hallerberg M., Basinger S. (1998), "Internationalization and Changes in Tax Policy in OECD Countries: the Importance of Domestic Veto Players", Comparative Political Studies, 31, 321-353.

Helleiner E. (1994), States and the Reemergence of Global Finance, Cornell University Press, London.

Holtz-Eakin D., Newey W., Rosen H. (1988), "Estimating Vector Autoregressions with Panel Data", Econometrica, 56, 1371-1395.

Im K.S., Pesaran M.H., Shin Y. (1997), Testing for Unit Roots in Heterogeneous Panels, Working Paper, University of Cambridge, December.

Islam M.Q. (2004), “The Long Run Relationship Between Openness and Government Size: Evidence from Bounds Test", Applied Economics, 36, 995-1000.

Iversen T., Cusack T. (2000), "The Causes of Welfare State Expansion: Deindustrialization or Globalization?", World Politics, 52, 313-349.

Kant C. (1996), Foreign Direct Investment and CapitalFlight, Princeton, Department of Economics, Princeton University.

Kar D.K. (1983), "Long-Term Trends in Openness of National Economies: Comment", Oxford Economic Papers, 35, 136-140.

Molana H., Montagna C., Violato M. (2004), On the Causal Relationship Between Trade Openness and Government Size: Evidence from 23 OECD Countries, mimeo.

Montiel P.J. (1994), "Capital Mobility in Developing Countries: Some Measurement Issues and Empirical Estimates", The World Bank Economic Review, 8, 311-350.

Moses J. (2000), «Floating Fortunes: Scandinavian Full Employment in the Tumultuous 1970s and 1980s», in Geyer R., Ingrebritsen C., Moses J. (eds.), Globalization, Europeanization and the end of Scandinavian social democracy?, New York and London, MacMillan.

Myøset L. (1996), «Nordic Economic Policies in the 1980s and in 1990s», mimeo.

Oates W. (1972), Fiscal Federalism, Harcourt Brace Jovanovich, New York.

Page B. (1997), Trouble for Workers and the Poor: Economic Globalization and the Reshaping of American Politics, mimeo.

Quinn D. (1997), "The Correlates of Change in International Financial Regulation", American Political Science Review, 91, 531-552.

Rodrik D. (1997), Has Globalization Gone Too Far, Institute for International Economics, Washington D.C.

Rodrik D. (1998), "Why Do More Open Economies Have Bigger Governments?", Journal of Political Economy, 106, 997-1032.

Ruggie J.G. (1982), "International Regimes, Transactions and Change: Embedded Liberalism in the Postwar Economic Order", International Organization, 36, 379-416.

Sanz I., Velázquez F.J. (2003), Does Globalization Increase Government Size? An Analysis of the Effects of Foreign Direct Investment on Total Government Expenditures and Its Components, mimeo. 
Schulze G., Ursprung H.W. (1999), "Globalization of the Economy and the Nation State", The World Economy, 22, 295-352.

Singh A. (2003), "Capital Account Liberalization, Free Long-Term Capital Flows, Financial Crises and Economic Development", Eastern Economic Journal, 29, 191216.

Slemrod J. (2004), “Are Corporate Tax Rates, Or Countries, Converging?”, Journal of Public Economics, 88, 1169-1186.

Swank D. (1998), "Funding the Welfare State: Globalization and the Taxation of Business in Advanced Market Economies", Political Studies, 46, 671-692.

Swank D. (2002), Global Capital, Political Institutions and Policy Change in Developed Welfare States, Cambridge University Press, Cambridge.

Tanzi V. (2000), Globalisation and the Future of Social Protection, Working Paper n.12, Washington, IMF, January.

Verdier D., Breen R. (2001), "Europeanization and globalization - Politics against markets in the European Union", Comparative Political Studies, 34, 227-262.

White L.J. (2003), "Aggregate Concentration in the Global Economy: Issues and Evidence", Centre for Law and Business Research Paper n. 03-15, New York University.

Whitman M.V.N. (1969), "Economic Openness and International Financial Flows", Journal of Money, Credit and Banking, 1, 727-749.

Wildavsky A. (1975), Budgeting: a Comparative Theory of Budgetary Processes, Boston, Little Brown. 
Table 1 - Time trend of the main variables

\begin{tabular}{|c|c|c|c|c|c|c|}
\hline & $C G_{\text {exp }}$ & $G G \_\exp$ & Trade & Fdi & Portfolio & Capital \\
\hline d75_85 & $\begin{array}{c}0.055 \\
(* * *)\end{array}$ & $\begin{array}{c}0.073 \\
(* * *)\end{array}$ & $\begin{array}{c}0.068 \\
(* *)\end{array}$ & -0.003 & 0.006 & 0.002 \\
\hline d85_95 & $\begin{array}{c}0.069 \\
(* * *)\end{array}$ & $\begin{array}{c}0.102 \\
(* * *)\end{array}$ & $\begin{array}{c}0.062 \\
(* *)\end{array}$ & $\begin{array}{c}0.011 \\
(* *)\end{array}$ & $\begin{array}{c}0.032 \\
(* * *)\end{array}$ & $\begin{array}{c}0.044 \\
(* * *)\end{array}$ \\
\hline d95_05 & $\begin{array}{c}0.028 \\
(*)\end{array}$ & $\begin{array}{c}0.070 \\
(* * *)\end{array}$ & $\begin{array}{c}0.136 \\
(* * *)\end{array}$ & $\begin{array}{c}0.058 \\
(* * *)\end{array}$ & $\begin{array}{c}0.090 \\
(* * *)\end{array}$ & $\begin{array}{c}0.148 \\
(* * *)\end{array}$ \\
\hline Constant & $\begin{array}{c}0.257 \\
(* * *)\end{array}$ & $\begin{array}{c}0.379 \\
(* *)\end{array}$ & $\begin{array}{c}0.382 \\
(* * *)\end{array}$ & $\begin{array}{c}0.017 \\
(* * *)\end{array}$ & 0.009 & $\begin{array}{c}0.026 \\
(* *)\end{array}$ \\
\hline F-test & $\begin{array}{l}11.1 \\
(* * *)\end{array}$ & $\begin{array}{l}16.0 \\
(* * *)\end{array}$ & $\begin{array}{c}5.6 \\
(* * *)\end{array}$ & $\begin{array}{c}70.8 \\
(* * *)\end{array}$ & $\begin{array}{c}36.9 \\
(* * *)\end{array}$ & $\begin{array}{c}69.1 \\
(* * *)\end{array}$ \\
\hline
\end{tabular}

Note: $\left(^{*}\right)$ Significant at 10 per cent level; (**) Significant at 5 per cent level; (***) Significant at 1 per cent level. Number of observations $=520$; Number of countries $=20$.

Variables : $C G \_$exp $=$Central Government expenditures in \% of GDP; GG_exp=General government expenditures in $\%$ of GDP; Trade =Import+Export in \% of GDP; Fdi=FDI inflows + FDI outflows in \% of GDP; Portfolio=Portfolio outflows+portfolio inflows in \% of GDP; Capital =Fdi+Portfolio

Source: Author's calculation on IFS data 
Table 2 - Government size, trade openness and capital openness

\begin{tabular}{|c|c|c|c|c|c|c|c|}
\hline & $\mathbf{A}$ & $\mathbf{B}$ & C & $\mathrm{D}$ & \begin{tabular}{l|l}
$\mathbf{E}$ & \\
\end{tabular} & $\mathbf{F}$ & $\mathbf{G}$ \\
\hline Coverage & $\begin{array}{r}\text { All countries, all } \\
\text { years }\end{array}$ & $\begin{array}{r}\text { All countries, all } \\
\text { years }\end{array}$ & $\begin{array}{r}\text { All countries, all } \\
\text { years }\end{array}$ & $\begin{array}{r}\text { All countries, all } \\
\text { years }\end{array}$ & $\begin{array}{r}\text { All countries, all } \\
\text { years }\end{array}$ & $\begin{array}{r}\text { European } \\
\text { countries, all } \\
\text { years }\end{array}$ & $\begin{array}{r}\text { European } \\
\text { countries, all } \\
\text { years }\end{array}$ \\
\hline Method & \begin{tabular}{|r|} 
OLS on pooled \\
data \\
\end{tabular} & PCSE & FGLS & Fixed Effects & Random effects & Fixed effects & Random effects \\
\hline & CG_exp & CG_exp & CG_exp & CG_exp & CG_exp & CG_exp & CG_exp \\
\hline Trade & \begin{tabular}{r|}
0.1099 \\
$(* * *)$
\end{tabular} & $\begin{array}{r}-0.0334 \\
(*)\end{array}$ & \begin{tabular}{r|}
-0.0072 \\
$(* *)$
\end{tabular} & $\begin{array}{r}-0.1095 \\
(* * *)\end{array}$ & \begin{tabular}{r|}
-0.1062 \\
$(* * *)$
\end{tabular} & $\begin{array}{r}-0.0720 \\
(* * *)\end{array}$ & $\begin{array}{r}-0.0563 \\
(* *)\end{array}$ \\
\hline FDI & $\begin{array}{r}-0.4339 \\
\ldots \ldots \ldots * \\
\ldots \ldots\end{array}$ & $\begin{array}{r}-0.2397 \\
(* * *) \\
\ldots \ldots \ldots \cdots\end{array}$ & $\begin{array}{r}-0.2110 \\
(* \ldots * *)\end{array}$ & $\begin{array}{r}-0.3840 \\
\ldots(* * *) \\
\ldots \ldots \ldots\end{array}$ & $\begin{array}{r}-0.3766 \\
\ldots(* * *)\end{array}$. & $\begin{array}{r}-0.6006 \\
\ldots(* * *) \\
\ldots . \cdots\end{array}$ & $\begin{array}{r}-0.6070 \\
\ldots(* * *)\end{array}$ \\
\hline Portfolio & $\begin{array}{r}-0.2974 \\
(* *)\end{array}$ & $\begin{array}{r}-0.0778 \\
(* *)\end{array}$ & -0.0387 & $\begin{array}{r}-0.1462 \\
\ldots(* * *)\end{array}$ & $\begin{array}{r}-0.1363 \\
\ldots \ldots(* *)\end{array}$ & $\begin{array}{r}-0.1163 \\
\ldots(* *)\end{array}$ & $\begin{array}{r}-0.1086 \\
\ldots \ldots(*)\end{array}$ \\
\hline GG Deficit & $\begin{array}{r}-0.6256 \\
\ldots(* * *)\end{array}$ & $\begin{array}{r}-0.5648 \\
(* * *)\end{array}$ & $\begin{array}{r}-0.5360 \\
\ldots(* * *)\end{array}$ & $\begin{array}{r}-0.7832 \\
(* * *)\end{array}$ & $\begin{array}{r}-0.7821 \\
\ldots(* * *)\end{array}$ & $\begin{array}{r}-0.8136 \\
(* * *)\end{array}$ & $\begin{array}{r}-0.8084 \\
\ldots(* * *)\end{array}$ \\
\hline Current account & $\begin{array}{r}-0.4488 \\
(* * *)\end{array}$ & $\begin{array}{r}-0.0968 \\
(* *)\end{array}$ & -0.0453 & $\begin{array}{r}-0.2506 \\
(* * *)\end{array}$ & $\begin{array}{r}-0.2369 \\
(* * *)\end{array}$ & $\begin{array}{r}-0.2862 \\
(* * *)\end{array}$ & $\begin{array}{r}-0.2979 \\
\ldots(* * *)\end{array}$ \\
\hline Income & $\begin{array}{r}-0.0000011 \\
(* *)\end{array}$ & $\begin{array}{r}-0.0000012 \\
(* * *)\end{array}$ & $\begin{array}{r}-0.0000011 \\
(* *) \\
\ldots \ldots \ldots \ldots\end{array}$ & $\begin{array}{r}-0.0000008 \\
(* * *)\end{array}$ & $\begin{array}{r}-0.0000009 \\
(* * *)\end{array}$ & $\begin{array}{r}-0.0000008 \\
\ldots \ldots \ldots(* *)\end{array}$ & $\begin{array}{r}-0.0000008 \\
(* * *)\end{array}$ \\
\hline Federal & & & & & $\begin{array}{r}-0.0772 \\
\ldots \ldots(* *)\end{array}$ & & $\begin{array}{r}-0.1167 \\
(* * *)\end{array}$ \\
\hline Time & $\begin{array}{r}0.0035 \\
(* * *)\end{array}$ & $\begin{array}{r}0.0035 \\
(* * *)\end{array}$ & $\begin{array}{r}0.0033 \\
(* * *)\end{array}$ & $\begin{array}{r}0.0047 \\
(* * *)\end{array}$ & $\left.\begin{array}{r}0.0045 \\
(* * *)\end{array}\right]$. & $\begin{array}{r}0.0050 \\
\ldots(* * *)\end{array}$ & $\begin{array}{r}0.0051 \\
\quad(* * *)\end{array}$ \\
\hline Population & $\begin{array}{r}-0.0005 \\
\ldots .(* * *) \\
\ldots . . . . . .\end{array}$ & $\begin{array}{r}-0.0008 \\
\ldots(* * *)\end{array}$ & $\begin{array}{r}-0.0005 \\
\ldots(* * *) \\
\ldots . . . . . . .\end{array}$ & $\begin{array}{r}-0.0010 \\
\ldots .(* * *)\end{array}$ & $\begin{array}{r}-0.0008 \\
\ldots .(* * *)\end{array}$ & 0.0029 & 0.0004 \\
\hline Constant & $\begin{array}{r}0.2644 \\
(* * *) \\
\end{array}$ & $\begin{array}{r}0.2916 \\
(* * *) \\
\end{array}$ & $\begin{array}{r}0.2811 \\
(* * *) \\
\end{array}$ & $\begin{array}{r}0.2616 \\
(* * *)\end{array}$ & $\left.\begin{array}{r}0.2791 \\
(* * *)\end{array}\right]$ & $\begin{array}{r}0.1736 \\
(* * *) \\
\end{array}$ & $\begin{array}{r}0.2498 \\
(* * *) \\
\end{array}$ \\
\hline $\begin{array}{l}\text { Number of observations } \\
\text { Number of countries }\end{array}$ & $\begin{array}{r}501 \\
20 \\
\end{array}$ & $\begin{array}{r}501 \\
20 \\
\end{array}$ & $\begin{array}{r}501 \\
20 \\
\end{array}$ & $\begin{array}{r}501 \\
20 \\
\end{array}$ & \begin{tabular}{r|}
501 \\
20
\end{tabular} & $\begin{array}{r}358 \\
15\end{array}$ & $\begin{array}{r}358 \\
15\end{array}$ \\
\hline F-test & \begin{tabular}{|c|}
31.2 \\
$(* * *)$ \\
\end{tabular} & & & $\begin{array}{r}120.1 \\
(* * *)\end{array}$ & & $\begin{array}{r}121.5 \\
(* * *)\end{array}$ & \\
\hline Ho: fixed effects $=0$ & & & & $\begin{array}{r}200.72 \\
(* * *) \\
\end{array}$ & & & \\
\hline$\overline{\text { Wald } \mathrm{chi}^{2}}$ & & $\begin{array}{r}342.6 \\
(* * *)\end{array}$ & $\begin{array}{r}559.6 \\
(* * *)\end{array}$ & & $\begin{array}{r}959.8 \\
(* * *)\end{array}$ & & $\begin{array}{r}954.9 \\
(* * *)\end{array}$ \\
\hline
\end{tabular}

Note: (*) Significant at 10 per cent level; (**) Significant at 5 per cent level; $(* * *)$ Significant at 1 per cent level.

Variables : $C G_{-}$exp $=$Central government expenditures in \% of GDP; Trade=Import+Export in \% of GDP; FDI=FDI inflows + FDI outflows in \% of GDP; Portfolio openness =Portfolio outflows+portfolio inflows in \% of GDP; GG deficit=General government deficit in \% of GDP; Cuurent account $=$ Current account balance in \% of GDP; Income $=$ Per capita income in US\$ at PPP; Federal=Dummy for federal countries; Population=Official population

Methods: PCSE=Panel Corrected Standard Errors; FGLS=Feasible Generalised Least Squares

\section{Source: Author's calculation on IFS data}




\section{Table 3 - Government size, trade openness and capital openness (changes)}

\begin{tabular}{|c|c|c|c|c|c|c|c|c|}
\hline & A] & B & Cl & D] & $\mathbf{E}$ & F) & $\mathbf{G}$ & $\mathbf{H}$ \\
\hline & $\begin{array}{r}\text { All countries, all } \\
\text { years }\end{array}$ & $\begin{array}{r}\text { All countries, all } \\
\text { years }\end{array}$ & $\begin{array}{r}\text { All countries, all } \\
\text { years }\end{array}$ & $\begin{array}{r}\text { All countries, all } \\
\text { years }\end{array}$ & $\begin{array}{r}\text { All countries, all } \\
\text { years }\end{array}$ & $\begin{array}{r}\text { All countries, all } \\
\text { years }\end{array}$ & $\begin{array}{r}\text { European } \\
\text { countries, all } \\
\text { years }\end{array}$ & $\begin{array}{r}\text { All countries, all } \\
\text { years } \\
\end{array}$ \\
\hline Method & Arellano-Bond & Arellano-Bond & Arellano-Bond & Arellano-Bond & Arellano-Bond & Arellano-Bond & Arellano-Bond & $\begin{array}{r}\text { First } \\
\text { differencing, } \\
\text { FGLS } \\
\end{array}$ \\
\hline & CG_exp & CG_exp & CG_exp & CG_exp & CG_exp & CG_exp & CG_exp & CG_exp \\
\hline$\overline{\Delta C G_{-} \_\exp _{\mathrm{t}-1}}$ & $\begin{array}{r}0.4252 \\
(* * *)\end{array}$ & $\begin{array}{r}0.5930 \\
(* * *)\end{array}$ & $\begin{array}{r}0.5024 \\
(* * *)\end{array}$ & $\begin{array}{r}0.7447 \\
(* * * *)\end{array}$ & $\begin{array}{r}0.7983 \\
(* * *)\end{array}$ & $\begin{array}{r}0.6144 \\
(* * *)\end{array}$ & $\begin{array}{r}0.8066 \\
(* * *)\end{array}$ & \\
\hline$\Delta \mathrm{CG}_{-} \mathrm{exp}_{\mathrm{t}-2}$ & 0.0257 & 0.0505 & $\begin{array}{r}0.0675 \\
(*)\end{array}$ & $\begin{array}{r}0.0799 \\
(*)\end{array}$ & 0.0488 & 0.0319 & 0.0105 & \\
\hline$\Delta$ trade $_{t}$ & $\begin{array}{r}-0.0498 \\
(* * *)\end{array}$ & $\begin{array}{r}-0.0909 \\
(* * *)\end{array}$ & $\begin{array}{r}-0.0813 \\
(* * *)\end{array}$ & $\begin{array}{r}-0.0508 \\
(* *)\end{array}$ & $\begin{array}{r}-0.0645 \\
-(* *)\end{array}$ & $\begin{array}{r}-0.0882 \\
-(* * *)\end{array}$ & $\begin{array}{r}-0.0470 \\
(* *)\end{array}$ & -0.0605 \\
\hline$\ddot{\Delta t r a d e}_{\mathrm{t}-1}$ & & & & 0.0291 & 0.0340 & & & \\
\hline$\ddot{\Delta} \mathrm{FDI}_{\mathrm{t}}$ & -0.2295 & $\begin{array}{r}-0.1471 \\
(* * *)\end{array}$ & -0.1524 & -0.2579 & -0.2388 & $\begin{array}{r}-0.1943 \\
(* *)\end{array}$ & -0.1844 & -0.0834 \\
\hline$\ddot{\Delta F D I} I_{t-1}$ & & & & 0.1052 & 0.1312 & & & \\
\hline $7_{\Delta \text { Portfolio }}$ & -0.0617 & $\begin{array}{r}-0.0872 \\
(* * *)\end{array}$ & -0.1105 & -0.0277 & -0.0167 & -0.1127 & -0.0446 & -0.0225 \\
\hline בPortfolio ${ }_{t-1}$ & & & & -0.0625 & -0.0408 & & & \\
\hline$\Delta$ GG deficit & $\begin{array}{r}-0.4909 \\
(* * *)\end{array}$ & $\begin{array}{r}-0.3374 \\
(* * *)\end{array}$ & $\begin{array}{r}-0.4042 \\
(* * *)\end{array}$ & & & $\begin{array}{r}-0.3200 \\
\ldots . . . . .\end{array}$ & & $\begin{array}{r}-0.4601 \\
(* * *)\end{array}$ \\
\hline$\Delta$ Current_account ${ }_{t}$ & $\begin{array}{r}-0.1727 \\
(* * *)\end{array}$ & $\begin{array}{r}-0.1749 \\
(* * *)\end{array}$ & $\begin{array}{r}-0.1943 \\
(* * *)\end{array}$ & & & $\begin{array}{r}-0.1927 \\
(* * *)\end{array}$ & & -0.0192 \\
\hline$\Delta$ Income $_{\mathrm{t}}$ & $\begin{array}{r}-0.0000007 \\
(* * *)\end{array}$ & $\begin{array}{r}-0.0000003 \\
(* * *)\end{array}$ & -0.0000006 & & & -0.0000003 & & $\begin{array}{r}-0.0000009 \\
(* * *)\end{array}$ \\
\hline${ }_{\Delta \text { Population }}$ & $\begin{array}{r}-0.0006 \\
(* * * *)\end{array}$ & $\begin{array}{r}-0.0002 \\
(* * *)\end{array}$ & $\begin{array}{r}-0.0003 \\
(* *)\end{array}$ & & & -0.000220 & & -0.000006 \\
\hline$\Delta$ Trade* $^{*}$ Capital $_{\mathrm{t}}$ & & & & & & 0.077607 & & \\
\hline$\Delta \mathbf{G G}$ deficit $_{\mathrm{t}-1}$ & & & & 0.0254 & -0.0018 & & 0.0122 & \\
\hline$\Delta$ Current_Account ${ }_{t-1}$ & & & & $\begin{array}{r}-0.1526 \\
\ldots(* * *)\end{array}$ & $\begin{array}{r}-0.1203 \\
\ldots(* *)\end{array}$ & & $\begin{array}{r}-0.1571 \\
(* * *)\end{array}$ & \\
\hline$\Delta$ Income $_{\mathrm{t}-1}$ & & & & -0.0000001 & 0.0000001 & & -0.0000001 & \\
\hline 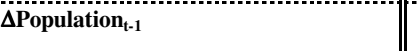 & & & & -0.0002 & -0.0001 & & 0.0019 & \\
\hline Constant & & & & $\begin{array}{r}0.0007 \\
(* *) \\
\end{array}$ & 0.0004 & $\begin{array}{r}0.0016 \\
(* * * *) \\
\end{array}$ & $\begin{array}{r}0.0006 \\
(*) \\
\end{array}$ & 0.0092 \\
\hline Number of observations & 420 & 420 & 420 & 420 & 420 & 420 & 296 & 471 \\
\hline Number of countries & 20 & 20 & 20 & 20 & 20 & 20 & 15 & 20 \\
\hline Sargan test & $\begin{array}{r}152.6 \\
(* * *)\end{array}$ & 521.2 & 491.0 & 466.6 & 475.1 & 531.7 & 334.3 & \\
\hline $\mathrm{H}_{0}:$ No autocorrelation of order 1 & \begin{tabular}{l|}
-6.7 \\
$(* * *)$ \\
\end{tabular} & \begin{tabular}{r|}
-10.44 \\
$(* * *)$ \\
\end{tabular} & \begin{tabular}{r|}
-9.57 \\
$(* * *)$ \\
\end{tabular} & \begin{tabular}{r|}
-12.5 \\
$(* * *)$ \\
\end{tabular} & \begin{tabular}{r|}
-12.64 \\
$(* * *)$ \\
\end{tabular} & \begin{tabular}{r|}
-10.76 \\
$(* * * *)$ \\
\end{tabular} & \begin{tabular}{r|}
-10.73 \\
$(* * *)$ \\
\end{tabular} & \\
\hline $\mathrm{H}_{0}$ : No autocorrelation of order 2 & -0.84 & -0.54 & -1.05 & 0.33 & 0.75 & -0.22 & 0.63 & \\
\hline Wald chi ${ }^{2}$ & $\begin{array}{r}942.3 \\
(* * *) \\
\end{array}$ & $\begin{array}{r}2745.1 \\
(* * *) \\
\end{array}$ & \begin{tabular}{r|}
2451.1 \\
$(* * *)$ \\
\end{tabular} & \begin{tabular}{r|}
1605.0 \\
$(* * * *)$ \\
\end{tabular} & $\begin{array}{r}1781.0 \\
(* * * *) \\
\end{array}$ & $\begin{array}{r}2794.1 \\
(* * *) \\
\end{array}$ & \begin{tabular}{r|}
1209.2 \\
$(* * * *)$ \\
\end{tabular} & $\begin{array}{r}407.6 \\
(* * *) \\
\end{array}$ \\
\hline Treatment of expalanatory variables & Exogenous & Predetermined & Endogenous & Endogenous & Predetermined & Predetermined & Predetermined & \\
\hline $\begin{array}{r}\text { Max number of lags to instrument the } \\
\text { dependent variable }\end{array}$ & 2 & 2 & 2 & 4 & 4 & 2 & 4 & \\
\hline $\begin{array}{r}\text { Max number of lags to instrument } \\
\text { explanatory variables }\end{array}$ & 4 & 4 & 4 & 4 & 4 & 4 & 4 & \\
\hline
\end{tabular}

Note: $(*)$ Significant at 10 per cent level; $(* *)$ Significant at 5 per cent level; (**) Significant at 1 per cent level.

Source: Author's calculation on IFS data 
Table 4 - Openness and general government expenditures

\begin{tabular}{|c|c|c|c|c|c|c|c|c|c|c|c|c|c|}
\hline & $\mathrm{A}$ & B & c & D & E & 息 & G & $\mathrm{H}$ & 1 & $\mathrm{~J}$ & $\mathrm{~K}$ & I & $\mathrm{M}$ \\
\hline & $\begin{array}{r}\text { All countries, alll } \\
\text { years }\end{array}$ & $\begin{array}{r}\text { All countries, all } \\
\text { years }\end{array}$ & $\begin{array}{r}\text { European } \\
\text { countries, all years }\end{array}$ & $\begin{array}{r}\begin{array}{r}\text { European } \\
\text { countries, all years }\end{array} \\
\end{array}$ & $\begin{array}{r}\text { All countries, all } \\
\text { years }\end{array}$ & $\begin{array}{r}\begin{array}{r}\text { European } \\
\text { countries, all years }\end{array} \\
\end{array}$ & $\begin{array}{r}\text { All countries, all } \\
\text { years }\end{array}$ & $\begin{array}{r}\text { All countries, all } \\
\text { years }\end{array}$ & $\begin{array}{r}\text { All countries, all } \\
\text { years }\end{array}$ & $\begin{array}{r}\text { All countries, all } \\
\text { years }\end{array}$ & $\begin{array}{r}\text { All countries, all } \\
\text { years }\end{array}$ & $\begin{array}{r}\text { All countries, all } \\
\text { years }\end{array}$ & $\begin{array}{r}\text { All countries, all } \\
\text { years }\end{array}$ \\
\hline Method & Fixed effects & Random effects & Fixed effects & Random effects & Arellano-Bond & Arellano-Bond & Fixed effects & Random effects & Arellano-Bond & Fixed effects & Random effects & Fixed effects & "Random effects \\
\hline & GG_exp & GG_exp & GG_exp & GG_exp & GG_exp & GG_exp & GG_social & GG_social & GG_social & GG__ex__A & GG_exp_A & GG__exp_B & GG__ex__B \\
\hline$\Delta G_{G} \_\exp _{t+1}$ & & & & & 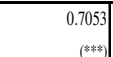 & $\begin{array}{r}0.6590 \\
(* * * *)\end{array}$ & & & $\begin{array}{r}0.6102 \\
(* * * *)\end{array}$ & & & & \\
\hline Trade & -0.1360 & $\begin{array}{r}-0.1122 \\
(* * 3)\end{array}$ & $\begin{array}{r}-0.1355 \\
(* * *)\end{array}$ & $\begin{array}{r}-0.1152 \\
(* * *)\end{array}$ & & & 0.0120 & 0.0197 & & $\begin{array}{r}-0.1086 \\
-(* 3 * 8)\end{array}$ & $\left.\begin{array}{r}-0.0983 \\
(\$ 8 * 4)\end{array}\right]$ & 0.0226 & 0.0826 \\
\hline$\Delta \Delta_{\text {trade }}$ & & & & & $\begin{aligned}-0.0877 \\
(3 * 54)\end{aligned}$ & -0.0758 & & & (2).1024 & & & & \\
\hline Fdi & $\begin{array}{c}-0.3039 \\
\ldots \ldots * 0\end{array}$ & $\begin{array}{l}-0.31009 \\
(3 * 8 \%)\end{array}$ & -0.4072 & 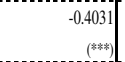 & & & -0.2367 & -0.2219 & & -0.2082 & $\begin{array}{c}-0.2120 \\
(* * *)\end{array}$ & - 0.3624 & -0.3946 \\
\hline$\Delta \mathrm{Fdi}_{\mathrm{t}}$ & & & & & -0.1898 & $-0.2560^{-10}$ & & & -0.1219 & & & & \\
\hline Portfolio & -0.0526 & -0.0364 & -0.0997 & -0.0844 & & & 0.0556 & $\begin{array}{r}0.0735 \\
(3)\end{array}$ & & 0.0065 & 0.0144 & 0.0236 & 0.0218 \\
\hline$\Delta$ Portfoliot $_{t}$ & & & & & -0.0622 & -0.0493 & & & 0.0477 & & & & \\
\hline GG deficit & -0.8316 & -0.8301 & 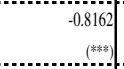 & - -0.8036 & & & $\begin{array}{c}-0.3082 \\
\ldots \\
(* * * * *\end{array}$ & -0.3053 & & -0.6956 & 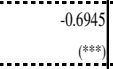 & -0.3943 & - 0.4229 \\
\hline$\Delta G G$ deficit $_{t}$ & & & & & $\begin{array}{c}-0.2751 \\
(* * * 8)\end{array}$ & $-0.3110^{\circ}$ & & & $\begin{array}{r}-0.0528 \\
(*)\end{array}$ & & & & \\
\hline Current account & -0.0202 & $\begin{array}{r}-0.0181 \\
\ldots(3 * 38 \\
\ldots\end{array}$ & -0.0501 & -0.0471 & & & $\begin{array}{c}-0.1580 \\
\ldots \\
(3 * * *\end{array}$ & -0.1344 & & -0.0612 & -0.0587 & -0.2821 & $\begin{array}{c}-0.3141 \\
(* * *) \\
(* 3)\end{array}$ \\
\hline$\Delta$ current_account $t_{t}$ & & & & & $\begin{array}{r}-0.1338 \\
-(8 * 58\end{array}$ & -0.2039 & & & -0.1484 & & & & \\
\hline Income & -0.000001 & 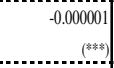 & $\begin{array}{r}-0.00002 \\
-\ldots\end{array}$ & -0.000002 & & & - -0.000001 & $\begin{array}{r}-0.00001 \\
-(* 38)\end{array}$ & & - & $\begin{array}{r}-0.000001 \\
\\
-\ldots * *\end{array}$ & -0.0000001 & -0.000004 \\
\hline sincome $_{1}$ & & & & & -0.00000003 & -0.00000043 & & & -0.00000052 & & & & \\
\hline Time trend & $\begin{array}{r}0.0046 \\
\ldots(* * * *)\end{array}$ & $\begin{array}{r}0.0045 \\
\ldots . . * * *\end{array}$ & $\begin{array}{r}0.0057 \\
\ldots \ldots * 3\end{array}$ & $\begin{array}{c}0.0056 \\
\ldots(* * 2)\end{array}$ & & & $\begin{array}{r}0.0046 \\
\ldots . .3 * *\end{array}$ & $\begin{array}{r}0.0041 \\
\ldots . \ldots * 8)\end{array}$ & & $\begin{array}{r}0.0033 \\
\ldots \ldots * * * \\
\end{array}$ & $\begin{array}{r}0.0032 \\
\ldots(* * *) \\
\ldots\end{array}$ & $\begin{array}{c}0.0029 \\
\ldots * \cdots\end{array}$ & $\begin{array}{r}0.0033 \\
\ldots(* * * *)\end{array}$ \\
\hline Federal & & -0.0327 & & -0.0248 & & & & 0.0627 & & & -0.0224 & & 0.0315 \\
\hline Population & -0.0004 & - & & -0.0006 & & & -0.0011 & -0.0009 & & 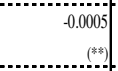 & -0.0005 & -0.0003 & -0.0007 \\
\hline$\Delta_{\text {Apopulation }}$ & & & & & -0.000037 & -0.0212 & & & $\begin{array}{r}0.0003 \\
(*)\end{array}$ & & & & \\
\hline Constant & $\begin{array}{r}0.4005 \\
(* * * * \\
\end{array}$ & $\begin{array}{r}0.4117 \\
(* * * * \\
\end{array}$ & 0.4023 & 0.4153 & $\begin{array}{r}0.0014 \\
(* * 8) \\
\end{array}$ & $\begin{array}{r}0.0031 \\
(* * *) \\
\end{array}$ & 0.2760 & 0.2402 & 0.0006 & $\begin{array}{r}0.3777 \\
(* * 8) \\
\end{array}$ & $\begin{array}{r}0.3779 \\
(* * * * 1 \\
\end{array}$ & $\begin{array}{r}0.3609 \\
(* * * * 6)\end{array}$ & $\begin{array}{r}0.3644 \\
(* * * *) \\
\end{array}$ \\
\hline $\begin{array}{l}\text { Number of observations } \\
\text { Number of countries }\end{array}$ & $\begin{array}{r}351 \\
19\end{array}$ & $\begin{array}{r}351 \\
19 \\
\end{array}$ & $\begin{array}{r}235 \\
14\end{array}$ & $\begin{array}{r}235 \\
14\end{array}$ & $\begin{array}{r}299 \\
19 \\
\end{array}$ & $\begin{array}{r}196 \\
14\end{array}$ & $\begin{array}{r}121 \\
14\end{array}$ & $\begin{array}{r}121 \\
14\end{array}$ & $\begin{array}{r}86 \\
12\end{array}$ & $\begin{array}{r}343 \\
19\end{array}$ & $\begin{array}{r}343 \\
19\end{array}$ & $\begin{array}{r}121 \\
14\end{array}$ & $\begin{array}{r}121 \\
14\end{array}$ \\
\hline F-test/Wald chi ${ }^{2}$ & $\begin{array}{l}50.9 \\
\\
\end{array}$ & $\begin{array}{r}409.8 \\
(* * 3) \\
\end{array}$ & $\begin{array}{l}49.2 \\
(* * 8)\end{array}$ & $\begin{array}{l}331.9 \\
(3 * *+\infty)\end{array}$ & $\begin{array}{r}1666.3 \\
(* * *) \\
\end{array}$ & $\begin{array}{r}1098.4 \\
(* * *)\end{array}$ & $\begin{array}{l}23.5 \\
(* * * *)\end{array}$ & $\begin{array}{l}188.9 \\
(* * 3)\end{array}$ & $\begin{array}{l}351.9 \\
(* * * *)\end{array}$ & $\begin{array}{l}52.5 \\
(* * *)\end{array}$ & $\begin{array}{r}422.5 \\
(* * * 4)\end{array}$ & $\begin{array}{l}13.4 \\
(* * * 4)\end{array}$ & $\begin{array}{l}113.5 \\
(* * * 4)\end{array}$ \\
\hline Ho: fixed effects $=0$ & $\begin{array}{l}71.8 \\
(* * *) \\
\end{array}$ & & $\begin{array}{l}70.8 \\
(* * * 8 \\
\end{array}$ & & & & $\begin{array}{r}86.4 \\
(3 * * 4) \\
\end{array}$ & & & $\begin{array}{l}128.5 \\
(* * *) \\
\end{array}$ & & $\begin{array}{l}45.2 \\
(* * * * * \\
\end{array}$ & \\
\hline $\begin{array}{c}\text { Treatment of expalanatory } \\
\text { variables } \\
\end{array}$ & & & & & Predetermined & Predetermined & & & Predetermined & & & & \\
\hline Sargan test & & & & & 366.4 & 226.3 & & & 122.0 & & & & \\
\hline Autocorrelation of order 1 & & & & & 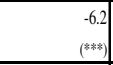 & $\begin{array}{l}-5.02 \\
(* * *) \\
\end{array}$ & & & $\begin{array}{r}-2.39 \\
(* * 4) \\
\end{array}$ & & & & \\
\hline Autocorrelation of order 2 & & & & & 0.05 & 0.17 & & & 0.30 & & & & \\
\hline
\end{tabular}

Note: (*) Significant at 10 per cent level; (**) Significant at 5 per cent level; $(* * *)$ Significant at 1 per cent level. Variables: See Table $2 . \Delta$ indicates first differencing; ${ }_{t-1}$ indicates one-period lag.

Not previously defined variables: GG_Social=(Health expenditures + Education expenditures + Social protection expenditures)/GDP;

GG_exp_A=General government expenditures excluding interest expenditures on GDP; GG_exp_B=General government expenditures excluding interest and defence expenditures on GDP.

Source: Author's calculation on OECD data 
Table 5 - Alternative specifications

\begin{tabular}{|c|c|c|c|c|c|}
\hline & $\mathbf{A}$ & B & C & $\mathbf{D}$ & $\mathbf{E}$ \\
\hline & $\begin{array}{r}\text { All countries, } \\
\text { all years }\end{array}$ & $\begin{array}{l}\text { Excluding Nordic } \\
\text { countries, all years }\end{array}$ & $\begin{array}{r}\text { All countries, } \\
\text { all years }\end{array}$ & $\begin{array}{r}\text { All countries, } \\
\text { all years }\end{array}$ & $\begin{array}{r}\text { All countries, } \\
\text { all years }\end{array}$ \\
\hline Method & FGLS & FGLS & FGLS & FGLS & FGLS \\
\hline & CG_exp & CG_exp & CG_exp & CG_exp & CG_exp \\
\hline$\overline{C G \_e x p_{t-1}}$ & & & & & $\begin{array}{r}0.9532 \\
(* * *)\end{array}$ \\
\hline Trade & 0.0551 & $\begin{array}{r}0.0390 \\
(* *)\end{array}$ & -0.0799 & -0.0064 & 0.0026 \\
\hline Trade $^{2}$ & $\begin{array}{r}-0.1545 \\
(* * *)\end{array}$ & & & & \\
\hline Fai & $\begin{array}{r}-0.1855 \\
(* * *)\end{array}$ & $\begin{array}{r}-0.1458 \\
(* * *)\end{array}$ & $\begin{array}{r}-0.3170 \\
(* * *)\end{array}$ & & $\begin{array}{r}-0.1149 \\
(* * *)\end{array}$ \\
\hline $\mathbf{F d i}^{2}$ & 0.0006 & & & & \\
\hline Portfolio & -0.0018 & -0.0337 & -0.0163 & & -0.0290 \\
\hline Portfolio $^{2}$ & -0.2968 & & & & \\
\hline G̈G̈Deficit & -0.5438 & -0.5580 & & -0.5346 & -0.1060 \\
\hline Current account & 0.0238 & -0.0272 & & -0.0444 & \\
\hline İncome & -0.00000071 & $\begin{array}{r}-0.000001 \\
(* * *)\end{array}$ & $\begin{array}{r}-0.000002 \\
(* * *)\end{array}$ & -0.00000̈i & -0.000001 \\
\hline Left & & & -0.0009 & & \\
\hline Proportiona....... & & & $\begin{array}{r}-0.0448 \\
(* * *)\end{array}$ & & \\
\hline Time trend & & & $\begin{array}{r}0.0030 \\
(* * *)\end{array}$ & $\begin{array}{r}0.0033 \\
(* * *)\end{array}$ & \\
\hline Federaìi" & & & -0.1993 & & \\
\hline Population & & & & -0.0005 & -0.00001 \\
\hline Maastricht & & & & & $\begin{array}{r}0.0077 \\
(* *)\end{array}$ \\
\hline Growth & & & & & -0.0142 \\
\hline FDII outflows & & & & -0.2772 & \\
\hline FDí inflows & & & & -0.1149 & \\
\hline P̈Í outflows & & & & $\begin{array}{r}-0.1165 \\
(* *)\end{array}$ & \\
\hline PII inflows & & & & 0.0259 & \\
\hline Constant & $\begin{array}{r}0.2770 \\
(* * *) \\
\end{array}$ & $\begin{array}{r}0.2934 \\
(* * *) \\
\end{array}$ & $\begin{array}{r}0.3958 \\
(* * *) \\
\end{array}$ & $\begin{array}{r}0.2806 \\
(* * *) \\
\end{array}$ & $\begin{array}{r}0.0124 \\
(* * *) \\
\end{array}$ \\
\hline Number of observations & 501 & 421 & 397 & 501 & 471 \\
\hline Number of countries & 20 & 17 & 16 & 20 & 20 \\
\hline F-test / Wald chi ${ }^{2}$ & $\begin{array}{r}369.6 \\
(* * *) \\
\end{array}$ & $\begin{array}{r}340.5 \\
(* * *) \\
\end{array}$ & $\begin{array}{r}654.6 \\
(* * *) \\
\end{array}$ & $\begin{array}{r}548.3 \\
(* * *) \\
\end{array}$ & $\begin{array}{r}15334.5 \\
(* * *) \\
\end{array}$ \\
\hline
\end{tabular}

Note: (*) Significant at 10 per cent level; (**) Significant at 5 per cent level; (***) Significant at 1 per cent level.

Variables not previously defined: Left=Dummy for centre-left governments; Proportional=Dummy for proportional electoral systems; Maastricht=Dummy for Maastricht Treaty; Growth=Rate of growth of GDP. $\mathrm{X}^{2}$ indicates the squared value of the variable

\section{Source: Author's calculation on IFS data}




\section{APPENDIX}

Table A.1 - Coverage for government expenditures

\begin{tabular}{|c|c|c|c|c|c|c|c|c|}
\hline & \multicolumn{4}{|c|}{ Central government expenditures } & \multicolumn{4}{|c|}{ General government expenditures } \\
\hline Country & Initial year & Final year & Missing years & $\begin{array}{c}\text { Number of } \\
\text { observations }\end{array}$ & Initial year & Final year & Missing years & $\begin{array}{c}\text { Number of } \\
\text { observations }\end{array}$ \\
\hline Australia & 1970 & 2002 & & 33 & 1970 & 2002 & & 33 \\
\hline Austria & 1967 & 1996 & & 30 & 1976 & 1996 & & 21 \\
\hline Canada & 1970 & 2001 & 2000 & 31 & 1970 & 2001 & 2000 & 31 \\
\hline Denmark & 1975 & 1998 & $1979 ; 1980$ & 22 & 1975 & 1998 & $1979 ; 1980$ & 22 \\
\hline Finland & 1975 & 1997 & & 23 & 1975 & 1997 & & 23 \\
\hline France & 1975 & 1997 & & 23 & 1995 & 1997 & & 3 \\
\hline Germany & 1991 & 1998 & & 8 & 1991 & 1998 & & 8 \\
\hline Greece & 1976 & 1999 & 1994; 1998 & 22 & 1988 & 1999 & $1994 ; 1998$ & 10 \\
\hline Ireland & 1974 & 1997 & & 24 & 1985 & 1997 & & 13 \\
\hline Italy & 1970 & 1998 & & 29 & 1980 & 1998 & & 19 \\
\hline Japan & 1977 & 1993 & & 17 & 1990 & 1993 & & 4 \\
\hline Netherlands & 1970 & 1997 & 1996 & 27 & 1970 & 1997 & 1989 & 28 \\
\hline New Zealand & 1972 & 2000 & 1989 & 28 & 1986 & 2000 & 1989 & 14 \\
\hline Norway & 1975 & 2003 & $2000 ; 2001$ & 27 & 1978 & 1999 & & 22 \\
\hline Portugal & 1975 & 1998 & 1981 & 23 & 1977 & 1998 & 1981; 1982 & 20 \\
\hline Spain & 1975 & 1998 & & 24 & & & & \\
\hline Sweden & 1970 & 2003 & $1998-2001$ & 30 & 1993 & 2003 & $1998-2001$ & 7 \\
\hline Switzerland & 1983 & 2003 & 1999-2001 & 18 & 1990 & 2002 & $1999 ; 2000$ & 11 \\
\hline United Kingdom & 1970 & 1997 & & 28 & 1970 & 1997 & & 28 \\
\hline United States & 1970 & 2003 & & 34 & 1970 & 2003 & & 34 \\
\hline Total & & & & 501 & & & & 351 \\
\hline
\end{tabular}




\section{Table A.2 - Definition of variables}

\begin{tabular}{|c|c|c|}
\hline Variables $(*)$ & Description & Source \\
\hline CG_exp & Central government expenditures on GDP & $\operatorname{IFS}(* *)$ \\
\hline GG_exp & $\begin{array}{l}\text { General government expenditures on GDP (also used excluding } \\
\text { interests - GG_exp_A - and interests and defence expenditures - } \\
\text { GG_exp_B) }\end{array}$ & OECD and elaborations on OECD data \\
\hline GG_Social & Health, education and social protection expenditures on GDP & Elaborations on OECD data \\
\hline Trade & Imports + Exports on GDP & Elaborations on IFS data \\
\hline FDI & $\begin{array}{l}\text { Foreign direct investment inflows + Foreign direct investment } \\
\text { outflows on GDP }\end{array}$ & Elaborations on IFS data \\
\hline Portfolio & Portfolio investment inflows + Portfolio investment outflows on GDP & Elaborations on IFS data \\
\hline Capital & FDI + Portfolio & Elaborations on IFS data \\
\hline Trade x Capital & Interaction between trade and capital & Elaborations on IFS data \\
\hline GG_Deficit & General government budget balance & IFS \\
\hline Current account & Current account balance & IFS \\
\hline Income & Income per capita in US\$ & Elaborations on IFS data \\
\hline Growth & Rate of growth of GDP & Elaborations on IFS data \\
\hline Population & Total official population & IFS \\
\hline Time & Time trend & Author's elaborations \\
\hline Left & Dummy variable for centre-left governments & Author's elaborations on official data \\
\hline Proportional & Dummy variable for proportional electoral systems & Author's elaborations on official data \\
\hline Maastricht & Dummy variable for Maastricht treaty & Author's elaborations \\
\hline FDI inflows & FDI inflows on GDP & Elaborations on IFS data \\
\hline FDI outflows & FDI outflows on GDP & Elaborations on IFS data \\
\hline PI inflows & PI inflows on GDP & Elaborations on IFS data \\
\hline PI outflows & PI outflows on GDP & Elaborations on IFS data \\
\hline Federal & Dummy for federal countries & Author's elaborations \\
\hline
\end{tabular}

$(*)$ Many variables are used in first difference (indicated by $\Delta$ ) and lagged (indicated by ${ }_{t-1}$ )

(**) Data for Netherlands and the Unted States are from OECD

Note: IFS=International Financial Statistics, International Monetary Fund; OECD=Organization for the Economic Cooperation and Development 
${ }^{1}$ I wish to thank Antonio Scialà, Federico Trionfetti and all participants (including two anonymous referees) to the International Symposium on "Globalization, public policy and multi-jurisdictional governance - The need for a common approach", held in Paris-Dauphine University, September 21-22, 2006 for useful comments on preliminary versions of this paper. Penetrating and insightful comments by two anonymous referees from the Journal of Public Policy are also gratefully acknowledged. The usual disclaimer applies.

${ }^{2}$ One reason might be that the dataset used in Swank (2002) extends only until 1993. At that time, capital openness was not yet playing a very prominent role in affecting national economies. It is worth recalling that in many European countries, capital flows were controlled for until the beginning of the Nineties. The trend for liberalisation in Europe began when Britain abolished its system of capital controls in 1979. The Delors Commission began in 1986 to formulate a plan for a series of directives aimed at liberalising capital movements among European countries unconditionally. The final directive on capital movements was issued in June 1988. An interesting historical perspective on this process is Abdelal (2006). For a detailed description of this process, see Helleiner (1994), especially chapter 7.

${ }^{3}$ This preference for public expenditures, however, does not entail that the analysis of taxes can be fully disregarded. As recently shown by Aizenman and Jinjarak (2006), globalization may have significant effects on tax bases of variously "hard to collect" and "easy to collect" taxes, as well as consequences on the total tax/GDP ratio.

${ }^{4}$ The International Monetary Fund (IMF) defines foreign direct investments (FDI) as those giving the investor an effective voice in management, while portfolio investments (PI) would give no significant influence over the operations of enterprises. In particular, a direct investor is an enteprise who owns 10 percent or more of the ordinary shares or voting power of another enterprise residing in another country. Also chains of ownership are possible, as direct investments may include entities that are subsidiaries, associates and branches. A portfolio investments, instead, is characterised by equity securities, debt securities in the form of bonds and notes, other money market instruments and financial derivatives. In subsidiaries a non-resident owns more than 50 per cent; in associates, a non-resident owns less than 50 per cent.

${ }^{5}$ This is the reason why, in economic series of flows and stock, by starting from any given stock in any given year, adding flows for a certain number of years do not give the amount of stock in the final year.

${ }^{6}$ The most common is a dummy variable for capital account openness on the basis of the International Monetary Fund Annual Report on Exchange Arrangements and Exchange Restrictions (AREARS).

${ }^{7}$ For example, if a lower growth raises expenditures for social benefits and depresses FDI inflows at the same time, it should also increase FDI outflows. A higher growth should instead increase FDI inflows and reduce FDI outflows and public expenditures for social benefits. In both cases, the algebraic sum of FDI inflows and outflows may signal a relevant capital mobility, limiting the relevance of growth as a driving factor in explaining the relation between capital flows and government size.

${ }^{8}$ Incidentally, this receives the suggestion by Alesina and Waczriag (1998) by which the observed correlation between openness and size may be due to the exclusion of a country size variable in regressions relating government size and trade openness. See also Frankel and Romer (1999).

${ }^{9}$ Results of tests are not reported in tables. They are available from the author upon request.

${ }^{10}$ FGLS is usually thought to be more efficient than alternative panel estimators. However, Beck and Katz (1995) have shown that, when using 10 to 20 panels and 10 to 40 time periods per panel (which is basically the case of the present analysis), Prais-Winsten estimates perform more satisfactorily, as the full FGLS variance-covariance estimates are anticonservative (standard errors are usually higher and statistical significance 'optimistic').

${ }^{11}$ The Arellano-Bond estimator is a GMM estimator using a first difference of the basic econometric specification including lags of the dependent variable on the right hand side and lags of independent variables as instruments for their first differences. See Arellano-Bond (1991).

${ }^{12}$ Note that this test differs from those proposed by Molana et al. (2004) and Islam (2004), in which the relationship among variables is tested country by country. Instead, the logic of this test resembles that developed by Im et al. (1997), where cointegration between variables is tested at a panel, rather than at an individual, level. In particular, tests are carried out at individual level, but what matters is the average value of the test not its individual values.

13 Incidentally, it is worth noting the persistently negative sign of per capita income, which may seem to be counterintuitive, especially if one thinks to a mechanism like the Wagner's law. In the logic of Wildavsky (1975), however, the negative sign of income may suggest a counter-Wagner law, by which the size of the public sector in relatively high-income countries (which is the case of our sample) may be inversely related to economic growth. 